\title{
A CRITICAL REVIEW ON EARLY-AGE CRACKING IN CONCRETE
}

\author{
P M B Raj Kiran Nanduri \\ HOD \& Assistant Professor, Department of of Civil Engineering, Samskruti College of \\ Engineering \& Technology, JNTUH- Jawaharlal Nehru Technological University Hyderabad, \\ Telangana, India \\ Corresponding Author
}

\begin{abstract}
The most widely used concrete versatile building material extensively used for the wide range of residential and industrial applications. It is a combination of three basic components: Portland cement, water and aggregates (gravel, rock or sand). Inappropriate mixing, unsuitable humidity and variations in the temperatures may lead to poor quality in concrete resulting to cracks Premature concrete cracking is a major issue in structures under working conditions, which is mainly depending on the nature of the material, hydration intensity, treatment atmosphere and healing conditions. This comprehensive review article will assist in identifying the common causes and Impact of early cracking of concrete and future prevention steps. Furthermore, the various types of early-age cracking, factors causing cracks such as temperature, thermal expansion, and tensile strength are discussed with simulation and identification of early-age cracking.
\end{abstract}

Keywords: Concrete, cracks, creeping, early-age, shrinkage

Cite this Article: P M B Raj Kiran Nanduri, A Critical Review on Early-Age Cracking in Concrete, International Journal of Civil Engineering and Technology, 11(12), 2020, pp. 74-83.

https://iaeme.com/Home/issue/IJCIET?Volume=11\&Issue $=12$

\section{INTRODUCTION}

Early cracking of concrete structures has a serious impact not only on structural stability but also reduces its service life. A significant problem arises from the concrete interactions with the environment and dynamic chemical and physical changes. As a result of the enormous number of factors concerned and the subjective presence of the phenomenon convergence, engineers depended totally on experiments were directed dependent on all around characterized and idealized notions of early cracking [1]. Early age is usually described in two main stages, the first few hours or days after concrete casting: setting and hardening [2]. A studies by the RILEM (International Union of Laboratories and Experts in Construction Materials, Systems and Structures) on initial-age thermal cracking of concrete Technical Panel and the review committee of the Japan Concrete Institute (JCI) offered no reasonable perspective [3]. For a 
long time, however, The mechanisms of early cracking in concrete and mortar product materials is of trend-setting research importance and the studies centered on different aspects of early cracking. The ever-increasing use of heavy-strength concrete and massive concrete frameworks in high-rise building demand makes the systemic technique which is necessary to prevent the early concrete cracking $[4,5]$.

The early-age breaking is known as cracking that usually occurs during the first seven days of concreting. However, The overall early-age cracking cap can be set assumed to be 60 days [6]. The origins of initial They studied the splitting of the concrete bridge wall. It recommended a holistic approach to ensure the correct design and quality of concrete goods, proper maintenance and curing techniques required to reduce the effects of early cracking. Incorrect moist healing strategies and the most likely causes of initial cracking are also inability to remove the plastic cracking threat during construction [7].

This review article presents a unique critical view on the specific categories and processes of the early-age cracking, triggers of cracking initiation and development, treatment and remediation of the early-age cracking. In addition to this certain key guideline that can be considered to minimize and prevent the early-age concrete cracking is discussed in an essay published internationally.

\section{CLASSIFICATION OF CONCRETE AND EARLY-AGE CRACKS}

Some researcher proposed a distinction depending on the compressive power of concrete and the bulk density [8]. The concrete can be defined as low-strength according to the compressive force (0 to $19 \mathrm{MPa}$ ), normal-strength (20 to $39 \mathrm{MPa})$, medium-strength (40 to $69 \mathrm{MPa}$ ), highstrength (70 to $119 \mathrm{MPa}$ ) and ultra-high-strength (120 to $1000 \mathrm{MPa})$. Based on the bulk density $\left(\mathrm{kg} / \mathrm{m}^{3}\right)$, concrete is classified as ultra-lightweight $\left(100\right.$ to $\left.500 \mathrm{~kg} / \mathrm{m}^{3}\right)$, lightweight (500 to 800 $\mathrm{kg} / \mathrm{m}^{3}$ ), moderate-strength lightweight $\left(800\right.$ to $1350 \mathrm{~kg} / \mathrm{m}^{3}$ ), structural lightweight (1350 to $1000 \mathrm{~kg} / \mathrm{m}^{3}$ ), normal weight (2000 to $\left.2600 \mathrm{~kg} / \mathrm{m}^{3}\right)$, heavyweight $\left(2600\right.$ to $\left.6100 \mathrm{~kg} / \mathrm{m}^{3}\right)[9,10]$.

The early-age cracks can be categorized as plastic shrinkage cracks, concrete settlement cracks, shrinkage drying cracks and thermal cracks. The cracks may also be classified by their orientation as longitudinal, transverse, diagonal and random [11, 12]. Classification is shown in the "Fig. 1".

\subsection{Plastic Shrinkage Cracks}

The plastic shortening cracks develop and occur within the first few hours after concreting when the concrete is in fresh condition. It is also triggered by the surface shrinkage of the material. At this point, concrete has significantly zero tensile potential [13].

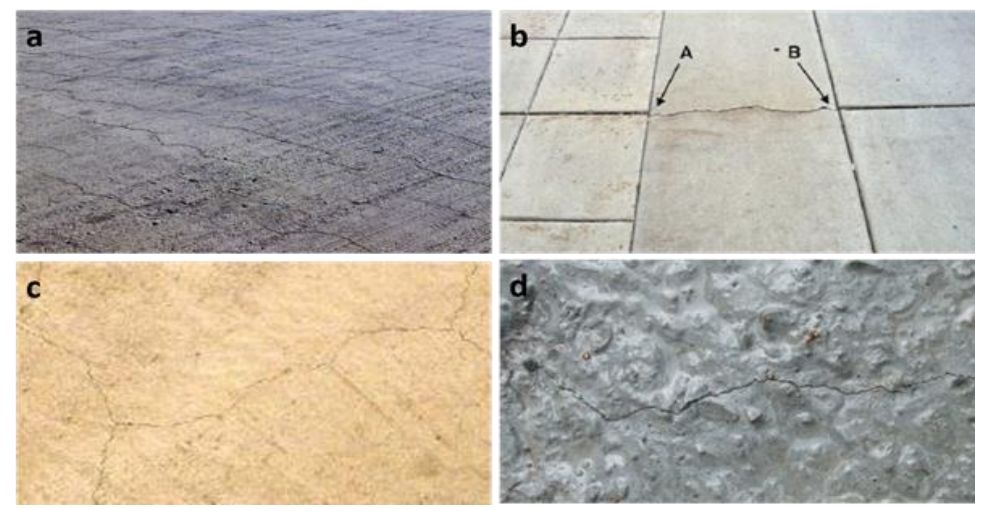

Figure 1 Types of cracks: (a) Plastic shrinkage cracks; (b) Plastic settlement cracks; (c) Drying shrinkage cracks; and (d) Autogenous shrinkage 


\subsection{Plastic Settlement Cracks}

The plastic settling cracks start after concreting and then vibrate and finish. The concrete begins to absorb its own weight and more likely to occur when vertical settling is limited by the horizontal slab reinforcement [14].

\subsection{Drying Shrinkage Cracks}

The drying shrinkage cracks in concrete are ignited by removing moisture from the cement paste. The tensile stress in concrete emerges while the other components restrict the shrinkage and can start contributing to cracking [15].

\subsection{Autogenous Shrinkage}

It is a major phenomenon in young concrete, and a decline in the amount of cement hydration triggered by the chemical cycle. During the hydration phase, the water is used quickly at a low water / cement ratio of less than about 0.42 , and generates very fine capillaries. The surface strain causes autogenous shrinkage during this procedure, likewise perceived as chemical shrinkage or self-dehydration [16].

\section{MECHANISM OF EARLY-AGE CRACKING}

The process of cracks was evaluated which formed during the cement hydration process as thermal stresses and, in most cases, during the first 12 and 24 hours following concrete placement. To initiate the crack, the temperature difference of approximately $20 \mathrm{UFF}$ (Universal Force Field) was maintained. Thermal fatigue is one of the main factors why concrete stiffening cracks and several researchers have revealed the process of early cracking [17].

Emborg and Bernander (1994) established a theoretical model for cracking caused by thermal stress, considering the various cracking phenomena and the impacts of concrete variations due to the temperature, restraint and mechanical behavior. The probability threshold for cracking was established as a stress criterion [18] by contrasting the tensile stress the actual tensile force of the matured concrete is calculated. Concerning the extent of concrete cracking due to thermal stress a simulation model was created. This model considered the degree of hydration, heat properties, (for example, the diffusivity of special heat and heat), thermal limit conditions and early cracking of mechanical properties [19]. Yuan and Wan (2002) Developed a micromechanical approach and quantitative formulas for producing young concrete properties to assess concrete placement potential in the early cracking. They assessed the effects of environmental factors and construction techniques on early cracking actions of concrete, including shell loss, healing conditions and alterations in ambient temperature and relative humidity [20].

Therefore, the mechanism of premature cracking is a complex interaction between the development of strength, the autogenic shrinkage process, creep deformation and stress relaxation [1].

\section{CAUSE OF EARLY-AGE CRACKING}

Early cracking occurs when the compressive pressure resulting from either small heat contractions or temperature variations in the concrete portion exceeds the concrete 's total tensile load potential $[21,22,23]$. Thermal stress can likewise cause early-age cracks (during development) or auxiliary damage, which may likewise diminish the functionality of the structure (for example snugness in water) and life span. Temperature changes are the essential 
clarification of why enormous slabs break early. This cracking is bound to spread from the focal point of the transverse segment where the temperature differs quickly [24].

The major cause of frequently develop early-age cracks in large concrete structures is a homogeneous alteration in the pressure associated with thermal and humidity gradients resulting from the hydration cycle in these structures. The noticeable impact on the rise in temperature, which seems to be the primary reason for significant changes in concrete thickness, results in a type of accumulation that shapes the thermal properties of concrete with the risk of cracking in the large base slabs [25].

The source of the early-age crack is, as per Subramaniam (2016), that the pressure of the cementitious matrix is lower than the aggregate thickness [26].

In VES-LMC (Very-early pressure latex-modified concrete) a further investigation was conducted to look into the causes of Yun and Choi's map and transverse cracking (2014). They also provided control methods to mitigate cracking in the field of Korea [27]. After concreting within several hours of placement, the map cracks were sparked by initial cracking of plastic shrinkage, inadequate and sluggish healing (use of healing molecule that was postponed until after tinning) and expanded within a week into larger, wider cracks. The mixture of thermal stress and dry decay leads to transverse cracking [28].

\subsection{Factors Affecting Early-Age Cracking}

Early cracking impacts can be characterized by following points: (1) Consistency of the building concrete, (2) the techniques of the construction, and (3) structural design factors. The high slump, excess cement content and high compressive strength are broadly taken as the key contributors to premature concrete cracking [29, 30]. Insufficient healing, lack of compaction and environmental conditions promoting the rapid evaporation of bleed water and contributing most to early cracking [31]. The structural design contributors significantly to cause early concrete cracking which includes low cover thickness and insufficient bar dimensions for stabilization and design [32].

Any cause drive upgraded impacts on cracking include high dissipation and weakening, high utilization of slump concrete, and unneeded measure of concrete water, lacking topreinforcing cover, inadequate solid inflexibility, restricted joint reinforcement detail among new and old surfaces, the grouping of pouring, weight and friction of the hardware and weight of the plan work. A few different considerations incorporate the evaporation rate including relative humidity, air density, the temperature of the air and concrete temperature, which supposedly affected early age cracking [33]. Table 1 shows the variables for early-age concrete cracking.

Table 1 Variables affecting the rigidity, heat and mechanical properties of early age concrete cracking [7].

\begin{tabular}{|l|l|}
\hline \multicolumn{1}{|c|}{ Assets } & \multicolumn{1}{c|}{ Theatures } \\
\hline Heat of hydration & $\begin{array}{l}\text { Cement form, total volume, and chemical } \\
\text { composition; environmental temperature, } \\
\text { and the admixtures used. }\end{array}$ \\
\hline Specific calorific capacity & $\begin{array}{l}\text { The composition of the mixture, the content } \\
\text { of moisture and the ambient temperature. }\end{array}$ \\
\hline Thermal conductivity & $\begin{array}{l}\text { The combined features of weight, water } \\
\text { content, temperature, and mineralogy. }\end{array}$ \\
\hline Thermal diffusivity & The type aggregate and the water content. \\
\hline $\begin{array}{l}\text { Coefficient of thermal } \\
\text { expansion }\end{array}$ & $\begin{array}{l}\text { Type \& nature of concrete, total aggregate, } \\
\text { and proportion of cement to water ratio, } \\
\text { temperature, and relative humidity. }\end{array}$ \\
\hline
\end{tabular}




\begin{tabular}{|l|l|}
\hline \multicolumn{2}{|c|}{ Mechanical Characterstics } \\
\hline Compressive strength & $\begin{array}{l}\text { Gel / space ratio of silicate calcium hydrate } \\
\text { (CSH), ratio of water/cement, cement, } \\
\text { presence of additives and healing condition }\end{array}$ \\
\hline Tensile strength & $\begin{array}{l}\text { Aggregate degradation Density and } \\
\text { aggregate gradation; curing form and } \\
\text { concrete age. }\end{array}$ \\
\hline Modulus of elasticity & $\begin{array}{l}\text { Temperature of the Concrete, water to } \\
\text { cement ratio, cement type, aggregate profile } \\
\text { and healing condition }\end{array}$ \\
\hline
\end{tabular}

\subsection{Detection of Early-Age Cracking}

Combrinck and Boshoff (2013) have proposed a mathematical model for estimating the degree of cracking of concrete plastic shrinkage (PShC). The model is related to the amount of freshly poured concrete water evaporated and can be described as follows:

PShC Severity $=E R \times t_{\text {set }}-W b l$

Where ER = evaporation rate $\left(\mathrm{kg} / \mathrm{m}^{2} / \mathrm{h}\right)$,

$\mathrm{t}_{\text {set }}=$ time between the concrete placement and the initial setting time $(\mathrm{h})$,

$\mathrm{Wbl}=$ total bleed water $\left(\mathrm{kg} / \mathrm{m}^{2}\right)$.

For a wide range of concrete mixtures with or without strengthening fibres, the suggested framework correlated effectively with the crack width caused by the cracking plastic shrinkage [34]. The research team studied early humidity and thermal characteristics and established linear relation of relative humidity to reduction [35]. The numerical model presented in the early periods of concrete solidifying, for example, huge base slabs, base squares, tank dividers and bridge projections; and encouraged investigation into the lead of reinforced solid structures. The 3D modeling of a concrete structure can be done taking into account the interaction between soil and construction, different technical considerations as well as specific concrete blends. The concept was implemented as computer programs: TEMWIL for thermal analysis of the moisture and MAFEM for stress analysis [36]. The ABAQUS 2017 software assessed a FEA model to confirm the early-age cracking distance by two parameters affecting early-age cracking, the time change in the elastic concrete container, and the time interval for positioning Table 2 [37].

Table 2 High tensile stress and high elastic stress on the concrete bridge, under the control of parameter-impact factors [37]

\begin{tabular}{|l|c|c|c|c|c|c|}
\hline \multicolumn{7}{|c|}{ Affecting parameters } \\
\hline & $\begin{array}{c}\text { The elastic modulus } \\
\text { of concrete changing } \\
\text { with time }\end{array}$ & \multicolumn{3}{|c|}{$\begin{array}{c}\text { Interval time of concrete } \\
\text { placements (days) }\end{array}$} \\
\cline { 2 - 7 } & $\begin{array}{c}\text { Conside } \\
\text { ration }\end{array}$ & $\begin{array}{c}\text { No } \\
\text { consider } \\
\text { ation }\end{array}$ & $\mathbf{7}$ & $\mathbf{1 4}$ & $\mathbf{2 1}$ & $\mathbf{2 8}$ \\
\hline $\begin{array}{l}\text { Maximum } \\
\text { tensile stress } \\
\begin{array}{l}\text { in the bridge } \\
\text { deck / MPa }\end{array}\end{array}$ & 7.167 & 9.471 & 5.558 & 6.937 & 8.315 & 9.23 \\
\hline $\begin{array}{l}\text { Maximum } \\
\text { elastic strain in } \\
\text { the bridge } \\
\text { deck }\end{array}$ & 0.000228 & 0.000236 & 0.000 & 0.000 & 0.000 & 0.00 \\
175 & 221 & 267 & 029 \\
7
\end{tabular}




\section{PREVENTIVE MEASURES OF EARLY-AGE CRACKING}

The cracking is an unavoidable by-product of reinforced concrete that should not have an adverse impact on structural efficiency if properly controlled [38]. The early-age cracking often poses several concerns that several remedial measures can reduce such risks. Precautions can be classified into two groups. The products and strategies of solution focused on the construction-based design and remedial methods. In building-based rehabilitation measures, the focus is on curing, cycle and environmental conditions, friction, the process of cooling, and shape. The prime emphasis of the remedies is on the rehabilitation of materials, concrete mixing and structural design.

Early-age cracking may be mitigated by decreasing the differences in the temperature by using shrinking ad-mixtures. Low-heated cement has been used to lower concrete fracturing temperatures. Shrinkage reduction ad-mixtures were also used to mitigate autogenous contraction pressures [39].

Precautions to be taken to control the loss of moisture when surface evaporation exceeds is to:

- erect temporary windbreaks and sunshades,

- application of a sprayable evaporation retardant,

- cover the flatwork with plastic sheeting between finishing passes,

- spraying the flatwork with fog,

- dampening the base material and shapes when inserting concrete,

- minimizing the concrete temperature by using chilled water or chipped ice, and

- using microfibers in the concrete mixture to improve the plastic concrete's tensile potential [40].

Several techniques for moisture-related cracking have been established including internal healing and the use of admixtures that minimize cement or shrinkage and other thermal cracking mitigation solutions $[41,42]$. Temperature control has also been demonstrated to be an effective means of preventing or reducing the risk of formation of concrete crack [24].

Early-age shrinkages and compressive creep tests were carried out to evaluate their impact on reinforced concrete cracking. They discussed the use of a fine ferronickel slaughtering aggregate (FNS) to reduce the possibility of initial cracking of ash-based concrete with travel. Their study involved $50 \%$ of natural sand replaced with FNS, and it was known that $25 \%$ of ordinary Portland cement replaced with fly ash mixed cement mitigated the risk of early cracking [43].

Curing also a major contributor to the mitigation of cracks. The application process is used to secure concrete from moisture depletion and maintain it within a safe range of temperatures, resulting in increased strength and less toughness of concrete. The speedy cure is a process which produces early solid concrete. In prefabrication, this type of strategy is especially useful if the strong early-age surface sheathing can be taken out within 24 hours and hence a reduced processing time leading to cost-effective benefits [44].

Yun and Choi (2014) provided control methods to minimize the occurrence of cracks on the ground. The following technique was prescribed after arranging and prior to concreting, for managing a map crack:

- add the curing compound as fast as possible,

- where appropriate, apply it after tinning, 
- fog as soon as it is clear.

For cross crack:

- early-fired concrete;

- weak cement like VES (Seasonal strength);

- low hydration temperature;

- total cement paste quantity; and

- $\quad$ unrestricted shrinking [27].

Recommendations for structural improvements and construction techniques to mitigate cracking of reinforced concrete decks were drawn upon the basis of bridge-deck field observations Cracks are recommended by reducing water and asphalt volume and preserving air quality above $6 \%$. Cracks said. An average cement content of $317 \mathrm{~kg} / \mathrm{m} 3$ for low-pitched high-performance concrete, an air content of 8.0 to 10 per cent and a slump of 38 to $75 \mathrm{~mm}$ were therefore required [45]

\section{CONCLUSION}

- The initial cracking in concrete structures is unavoidable, with time leading to significant increases in crack width following cracking and further deformation induced.

- Although a few logical examinations have been completed over for a long time to conquer the reasons for early cracking issues, there is still worry that the data will fundamentally arrive at engineers on the spot.

- It should be mentioned that much of the response to the problem of early cracking is focused on building equipment.

- Improving workers' qualifications and training for the concrete construction activities before they are put to work would help resolve the problem.

- This review paper will provide specific examples of the various forms of early-age concrete cracking.

- In the course of planning, materials and mixing criteria, construction practices and internal and external loading conditions that affect early concrete cracking is classified.

- The remedial steps for the reduction of early cracking have also been identified.

\section{FUTURE SCOPE}

It is mandatory.

\section{REFERENCES}

[1] Mihashi, H., \& Leite, J. P. D. B. (2004). State-of-the-art report on control of cracking in early age concrete. Journal of Advanced Concrete Technology, 2(2), 141-154.

[2] Pane, I., \& Hansen, W. (2002). Early age creep and stress relaxation of concrete containing blended cements. Materials and structures, 35(2), 92.

[3] Bentur, A., \& Kovier, K. (2001). RILEM International Conference on Early Age Cracking in Cementitious Systems (EAC'01). Materials and Structures, 34(7), 446.

[4] Safiuddin, M., Kaish, A. B. M., Woon, C. O., \& Raman, S. N. (2018). Early-age cracking in concrete: causes, consequences, remedial measures, and recommendations. Applied Sciences, 8(10), 1730. 
[5] Kalra, M., \& Mehmood, G. (2018, October). A Review paper on the Effect of different types of coarse aggregate on Concrete. In IOP Conference Series: Materials Science and Engineering (Vol. 431, No. 8, p. 082001). IOP Publishing.

[6] Safiuddin, M., Kaish, A. B. M., Woon, C. O., \& Raman, S. N. (2018). Early-age cracking in concrete: causes, consequences, remedial measures, and recommendations. Applied Sciences, 8(10), 1730.

[7] Wright, J. R., Rajabipour, F., Laman, J. A., \& Radlińska, A. (2014). Causes of early age cracking on concrete bridge deck expansion joint repair sections. Advances in Civil Engineering, 2014.

[8] Sojobi, A. O., Aladegboye, O. J., \& Awolusi, T. F. (2018). Green interlocking paving units. Construction and Building Materials, 173, 600-614.

[9] Song, P. S., \& Hwang, S. (2004). Mechanical properties of high-strength steel fiber-reinforced concrete. Construction and Building Materials, 18(9), 669-673.

[10] Davraz, M., Ceylan, H., Topçu, İ. B., \& Uygunoğlu, T. (2018). Pozzolanic effect of andesite waste powder on mechanical properties of high strength concrete. Construction and Building Materials, 165, 494-503.

[11] Patnaik, A., \& Baah, P. (2015). Cracking behavior of structural slab bridge decks (No. FHWA/OH-2015/4).

[12] Leonhardt, F. (1977). Crack control in concrete structures. International Association for Bridge and Structural Engineering.

[13] Shaeles, C. A., \& Hover, K. C. (1988). Influence of mix proportions and construction operations on plastic shrinkage cracking in thin slabs. Materials Journal, 85(6), 495-504.

[14] Fookes, P. G., \& Lee, E. M. (2019). The engineering geology of concrete in hot drylands. Quarterly Journal of Engineering Geology and Hydrogeology, 52(3), 257-279.

[15] American Concrete Institute. Committee 224. (1998). Causes, evaluation, and repair of cracks in concrete structures. American Concrete Institute.

[16] Kosmatka S.H. and Wilson M.L.(2016). "Design and control of concrete mixtures", 16th Editi, Skokie, Illinois: Portland Cement Association,

[17] Aktan, H. M., Fu, G., Dekelbab, W., \& Attanayaka, U. (2003). Investigate causes \& develop methods to minimize early-age deck cracking on Michigan bridge decks (No. Research Report $\mathrm{RC}-1437)$.

[18] Emborg, M., \& Bernander, S. (1994). Assessment of risk of thermal cracking in hardening concrete. Journal of Structural Engineering, 120(10), 2893-2912.

[19] Wu, S., Huang, D., Lin, F. B., Zhao, H., \& Wang, P. (2011). Estimation of cracking risk of concrete at early age based on thermal stress analysis. Journal of Thermal Analysis and Calorimetry, 105(1), 171-186.

[20] Yuan, Y., \& Wan, Z. L. (2002). Prediction of cracking within early-age concrete due to thermal, drying and creep behavior. Cement and concrete research, 32(7), 1053-1059.

[21] Bamforth, P. B. (2007). Early-age thermal crack control in concrete (Vol. 660). London: Ciria.

[22] Carino, N. J., \& Carino, N. J. (1995). Prediction of cracking in reinforced concrete structures. US Department of Commerce, National Institute of Standards and Technology.

[23] Gilbert, R. I. (2017). Cracking caused by early-age deformation of concrete-prediction and control. Procedia Engineering, 172(3), 13-22.

[24] Bilčík, J., Sonnenschein, R., \& Gažovičová, N. (2017). Causes of early-age thermal cracking of concrete foundation slabs and their reinforcement to control the cracking. Slovak Journal of Civil Engineering, 25(3), 8-14. 
[25] Klemczak, B., Batog, M., Pilch, M., \& Żmij, A. (2017). Analysis of cracking risk in early age mass concrete with different aggregate types. Procedia engineering, 193, 234-241.

[26] Subramaniam, K. V. (2016). Identification of early-age cracking in concrete bridge decks. Journal of Performance of Constructed Facilities, 30(6), 04016054.

[27] Yun, K. K., \& Choi, P. (2014). Causes and controls of cracking at bridge deck overlay with very-early strength latex-modified concrete. Construction and Building Materials, 56, 53-62.

[28] Krauss, P. D., \& Rogalla, E. A. (1996). Transverse cracking in newly constructed bridge decks (No. Project 12-37 FY'92).

[29] Brown, M., Sellers, G., Folliard, K. J., \& Fowler, D. W. (2001). Restrained shrinkage cracking of concrete bridge decks: State-of-the-Art Review (No. FHWA/TX-0-4098-1).

[30] Kochanski, T., Parry, J., Pruess, D., Schuchardt, L., \& Ziehr, J. (1990). Premature cracking of concrete bridge decks study. Final Report. Wisconsin Department of Transportation, Madison, WI.

[31] McLeod H.A.K., Darwin D. and Browning J.(2009). "Development and construction of LowCracking High-Performance Concrete (LC-HPC) bridge decks: construction methods, specifications, and resistance to chloride ion penetration," SM Report 94, University of Kansas Center for Research, Lawrence, Kan, USA

[32] Schmitt T.R. and Darwin D.(1995). "Cracking in concrete bridge decks," Tech. Rep. KTRAN:KU-94-1, Kansas Department of Transportation, Topeka, Kan, USA

[33] Esping, O. S. K. A. R. (2007). Early age properties of self-compacting concrete. Effects of fine aggregate and limestone filler Ph. D. Sweden: Chalmers University of Technology.

[34] Combrinck, R., \& Boshoff, W. P. (2013). Typical plastic shrinkage cracking behaviour of concrete. Magazine of Concrete Research, 65(8), 486-493.

[35] Jonasson, J. E., Groth, P., \& Hedlund, H. (1994, October). Modelling of temperature and moisture field in concrete to study early age movements as a basis for stress analysis. In Proceedings of International Symposium Thermal Cracking in Concrete at Early Ages (pp. 45-52).

[36] Klemczak, B., \& Knoppik-Wróbel, A. (2015). Reinforced concrete tank walls and bridge abutments: Early-age behaviour, analytic approaches and numerical models. Engineering Structures, 84, 233-251.

[37] Chang, S., Yang, M., Sun, Y., \& Liu, K. (2019). Calculation Method of Early-Age Crack Width in Reinforced Concrete Bridge through a Nonlinear FEA Model. KSCE Journal of Civil Engineering, 23(7), 3088-3096.

[38] Kozikowski, R. L., \& Suprenant, B. A. (2015). Controlling early-age cracking in mass concrete. Concrete International, (3), 59-62.

[39] Sule, M., \& Van Breugel, K. (2004). The effect of reinforcement on early-age cracking due to autogenous shrinkage and thermal effects. Cement and Concrete Composites, 26(5), 581-587.

[40] Hover, K. C. (2006). Evaporation of water from concrete surfaces. ACI materials journal, 103(5), 384.

[41] Fernandes, F., Manari, S., Aguayo, M., Santos, K., Oey, T., Wei, Z., ... \& Sant, G. (2014). On the feasibility of using phase change materials (PCMs) to mitigate thermal cracking in cementitious materials. Cement and Concrete Composites, 51, 14-26.

[42] Sant, G. N. (2009). Fundamental investigations related to the mitigation of volume changes in cement-based materials at early ages. Purdue University. 
[43] Nguyen, Q. D., Khan, M. S. H., Xu, T., \& Castel, A. (2019). Mitigating the Risk of Early Age Cracking in Fly Ash Blended Cement-Based Concrete Using Ferronickel Slag Sand. Journal of Advanced Concrete Technology, 17(6), 295-308.

[44] Gokul T., Arun M. and Arunachalam N.(2016). "Effects of different types of curing on strength of concrete", International journal of innovative research in science, engineering and technology, vol. 5, no. 2, pp. 1643-1649

[45] Browning, J., Darwin, D., \& Hurst, K. F. (2009). Specifications to reduce bridge deck cracking. HPC Bridge Views, (55). 